\title{
Rewards in a Not-for-Profit Organisation
}

\author{
Ron Kluvers \\ Swinburne University, Australia \\ John Tippet \\ Victoria University, Australia
}

\begin{abstract}
This paper reports on a study undertaken in a Not-For-Profit (NFP) organisation providing services for people with disabilities. The organisation concerned is made up of two units and in response to a changing funding model, has introduced a performance bonus in one of the units. This situation raises the question as to how extrinsic rewards, as compared with intrinsic rewards, are perceived by staff of NFP organisations as a source of motivation. The effectiveness of an organisation is influenced by the motivation of its employees. Governance is concerned with enhancing the effectiveness of organisations. Because employee motivation impinges so critically upon effectiveness of the operations of the organisation, it is a governance issue. Data was gathered through a survey that had a number of statements about intrinsic and extrinsic rewards. The responses of the staff were indicated using a fivepoint Likert scale. The frequencies and percentages of those responses are reported in this study. The important findings of the study are that intrinsic rewards play a significant role in the motivation of staff in this NFP organisation. Extrinsic rewards were regarded in a more ambiguous way.
\end{abstract}

\section{Keywords}

Intrinsic rewards, extrinsic rewards, motivation, not-for-profit organisations

\section{Introduction}

The aim of this study is to understand the factors that motivate employees to work in a Not-for-Profit (NFP) organisation, and therefore to understand an important aspect of governance. In particular, this study considers the importance of intrinsic factors in the motivation of people working and remaining in the NFP sector despite being paid less than their private sector counterparts.

Employee motivation is a critical aspect of organisational effectiveness. Governance is vitally concerned with an organisation achieving its objectives, and this will not happen with poorly-motivated staff. Hence, motivation is a governance issue. A second aspect of governance is overseeing organisational practices that work towards the efficient use of available resources. These include employees, of course, and in our particular case the issue of staff turnover. In a study undertaken by Graffam, Noblet, Crosbie

Copyright (C) 2009 Victoria University. This document has been published as part of the Journal of Business Systems, Governance and Ethics in both online and print formats. Educational and non-profit institutions are granted a nonexclusive licence to utilise this document in whole or in part for personal or classroom use without fee, provided that correct attribution and citation are made and this copyright statement is reproduced. Any other usage is prohibited without the express permission of the and Lavelle (2005) it was found that the employee turnover rate in the open disability employment industry was 27.3 per cent, in comparison to the all industries average of 12.4 per cent (ABS, 2002). The higher than average employee turnover is problematic for the industry, and hence an issue needing to be addressed in the interest of good governance. According to Graffam, Noblet, Crosbie and Lavelle (2005) the costs and 
unnecessary disruptions to the industry, including recruitment of replacement personnel, administrative, advertising and screening costs are significant.

This paper contributes to the knowledge of governance in the not-for-profit sector by testing the applicability to the latter sector of the generally-accepted notion that employees are motivated primarily by pay. The hypothesis to be tested is that employees are motivated by intrinsic rewards. Frey (1997), whilst essentially concerned with the crowding-out effect extrinsic incentives may have on intrinsic work motivation, suggests that when employees' income rises above subsistence level, they seek meaning in work; that is to say, intrinsic motivation becomes more important. Since employees in the organisation that is the subject of this study were not dissatisfied with their pay (see section 6 , Table 1), it may be inferred that they considered their pay to be above subsistence level; and therefore that intrinsic motivation was likely to be more important to them.

According to Ryan and Deci (2000), the term, "extrinsic motivation" is the attainment of a separable outcome from the performance of an activity; whereas "intrinsic motivation" is the performance of an activity for the inherent satisfaction of the activity itself. The present study examines both intrinsic and extrinsic rewards in an organisation made up of two units: one unit paying a performance bonus (an obvious extrinsic reward) and the other unit not, thus providing an ideal context in which to study the motivational effect of an extrinsic reward compared with the motivational effect of intrinsic rewards.

Gupta and Mitra (1998) argue that money is an important motivator, although the NFP literature indicates that intrinsic rewards are important to staff in NFP sector organisations and argues that classical agency theory is inadequate to explain the motivation of employees in this sector. Extrinsic rewards, such as monetary bonuses, are incentives provided by others and are external to the recipient. Herzberg (2003) argues that money is a "hygiene factor", and cannot be a source of motivation. However, if the hygiene factor (in this case, pay) is perceived to be inadequate then the employee will be dissatisfied. Intrinsic rewards are personal, "internal" responses, such as satisfaction or pride in an accomplishment. According to Ryan and Deci (2000) fun and challenge are of greater significance to an intrinsically motivated person than external pressures and rewards.

The debate about the influence of extrinsic and intrinsic rewards on motivation appears to be cast in dichotomous terms. However, much of the evidence indicating the importance of extrinsic rewards comes from the business sector or was obtained using an experimental research method in which the context of the task is not considered. In fact participants in experiments are often required to perform trivial tasks. The focus of the experiment is usually to determine the effects of changing the level or frequency of rewards rather than what the participants are required to do. However, in a human services context the nature of the task is not trivial and in all likelihood is the reason for the employee being in the sector (Schepers et al., 2005). The fact that an individual is working in a NFP organisation is indicative of a set of values in which extrinsic rewards are not the first consideration (Weisbrod (1983), Preston (1989), Roomkin and Weisbrod (1999)).

The paper continues (section 2) with a statement of the context of the research. In section 3 the literature dealing with intrinsic and extrinsic rewards is discussed; followed by section 4 which is a brief description of the organisation in the study. In section 5 the research question is described and the research method outlined. Section 6 provides the statistical analysis, and section 7 discusses the findings. Finally, in section 8 conclusions are drawn.

\section{The Context of this Study}

Employee motivation cannot be examined in isolation from its organisational context since it is the activities undertaken within an organisation that are being considered; and in particular it is human motivation that encourages the individual to remain with the organisation (Berry, Broadbent and Otley 1995; Schepers et al. 2005). In this study the context is particularly relevant as it defines the activities and rewards (Jobome, 2006). Of particular significance is that any intrinsic rewards staff receive are closely linked to the type of work they do. 
In a study undertaken by Graffam, Noblet, Crosbie and Lavelle (2005) it was found that the employee turnover rate in the open disability employment industry was 27.3 per cent, in comparison to the all industries average of 12.4 per cent (ABS, 2002). The higher than average employee turnover is problematic for the industry. According to Graffam, Noblet, Crosbie and Lavelle (2005) the costs and unnecessary disruptions to the industry, including the recruitment of replacement personnel, administrative, advertising and screening costs are significant. Other costs include interviewing, security checks, the processing of references, lost productivity, the cost of training, and costs associated with the period prior to departure when employees tend to be less productive. Therefore the issue of workforce motivation is important for the sector.

\section{Rewards in the Not-for-Profit Sector}

The literature points to two contrary positions regarding the motivational effect of rewards. One position argues that extrinsic rewards will be a source of motivation, while the other argues that intrinsic rewards have greater impact, particularly in a non-commercial setting. This argument has important implications for governance in the NFP sector.

Agency theory suggests that people are motivated by extrinsic rewards and that employees will only perform tasks for which they are rewarded (Jensen and Meckling 1976; Eisenhardt 1989; Baiman 1990). This means that people will only work to the best of their abilities if they consider the reward to be adequate. According to Jensen and Meckling (1976) agency theory states that individuals are wealth maximisers. Altruism is not considered to be a part of the principal/agent relationship.

Ryan and Deci (2000) point out that the question of extrinsic/intrinsic motivation is a complex issue. In particular, the significance of an extrinsic reward is related to the values of the employee; in other words, the efficacy of the extrinsic reward is linked to what the employee believes to be important. Gupta and Mitra (1998) using meta-analysis found that financial incentives are strong motivators. They found that financial incentives were particularly powerful with respect to performance quantity. However, results were uncertain when regarding performance quality - an important consideration in the human services sector and particularly important in the NFP sector where maintaining organisational effectiveness - namely, service quality - is an important aspect of governance.

The results of research in the public sector appear to contradict the conclusions of Gupta and Mitra. According to O'Donnell and Shields (2002) the application of performance-related pay in the Australian Public Service (APS) has been problematic. Similarly the research of Marsden and Richardson (1994) found that performance-related pay had limited motivational effects. O'Donnell (1998) found that the attempt to apply performance bonuses to senior officers of the APS did not contribute to an improvement in performance. Also, the OECD (1993) questioned the motivational effects of pay increases and bonuses, particularly for senior public service managers. According to Gaertner and Gaertner (1985), performance appraisals that placed emphasis on the development needs of managers had the potential to increase the performance of the manager. This finding is in line with Ryan and Deci's (2000) idea of assimilation: the assimilation of the organisation's demands with one's own values and needs. Gaertner and Gaertner's finding suggests that extrinsic rewards coupled with training or feedback that could assist the individual to improve performance have greater significance than extrinsic rewards alone. Given the problematic nature of performance-related pay in the public sector, there is reason to suggest that performance related pay in the NFP sector will be problematic also.

Governance includes setting the mission of an organisation. Dowling and Richardson (1997) showed that UK National Health Service (NHS) managers were positive about role and goal clarity, and feedback and support from superiors. Hence, these factors - clarity of goal and support from superiors - are significant motivators and are therefore clearly important to the effective management of organisations and, by implication, important to good governance.

Redman et al. (2000) found that two-thirds of NHS managers reported that a performance management system contributed to their motivation. However, the performance-related pay component of the system 
was perceived negatively. Respondents were particularly critical of performance pay being given to individuals in instances where performance was heavily dependent on a team effort. The findings of Gaertner and Gaertner (1985), Dowling and Richardson (1997), Redman et al. (2000) and O'Donnell and Shields (2002) are supported by Frey's (1997) contention that (once pay exceeds a subsistence level) intrinsic factors are stronger motivators; and suggest that extrinsic rewards by themselves are problematic and staff motivation also requires intrinsic rewards such as pride at doing a good job and a sense of doing something worthwhile.

People working in the third sector do so despite generally lower pay, because they consider the task to be important. Williams (1998) points out that people have different values, motives and perceptions and are not passive recipients who will automatically respond to work systems as management wishes. In keeping with the findings of Etzioni (1988) and Larson (1977), values, as pointed out by Williams, are considered to be important in the development of an individual's commitment to an organisation. The importance of altruistic values in relation to employment in the third sector was highlighted by Jobome (2006), who found in his study of management pay in large UK NFPs that intrinsic rewards dominated extrinsic ones.

Holcombe (1995), consistent with the argument of Ryan and Deci (2000), argues that bringing about a congruence of individual values with organisational values is creating a sense of mission that is an employee's personal commitment to the organisation. In her study of the Grameen Bank in Bangladesh, Holcombe demonstrates how important employee identification with the organisation's goals and values is to the achievement of the organisation's mission. Holcombe appears to be in total agreement with Ryan and Deci (2000); also with Brown and Yoshioka (2003). However, the latter found that a perception that pay was inadequate was a source of dissatisfaction, which could lead to a reduction of motivation. This point was also emphasised by Herzberg (2003), and is implicit in Frey (1997). Thus, extrinsic rewards cannot be ignored. In addition, Berry, Broadbent and Otley (1995) point out that people working in the 'caring services' may consider remunerative motivation as less important than the normative reward of 'doing a worthwhile job'. Similar conclusions were drawn by Bouillon et al. (2006) in their study of hospital managers: their research indicates that hospital managers were not motivated by individual opportunism alone.

The literature has clearly argued that financial incentives and controls may not be effective motivators in NFP's. Speckbacher (2003) states that NFP organisations may more easily attract committed employees precisely because the absence of owners is a signal to such employees that their selflessness will not be enriching someone else. Thus, the maintenance of a sense of care and of doing a worthwhile job is important to the effective operation of an NFP, and hence very important to its governance.

\section{The Organisation}

The organisation in which this study took place provides services for people with disabilities and is divided into two units: the Employment unit and the Lifestyles unit. The Employment unit is the larger of the two and finds employment for people with disabilities in the open market; and the Lifestyles unit provides independent living skills for intellectually disabled people. The organisation is regarded as successful as it has operated for six years, has a staff of about 60 people and has received public recognition for its work, including complimentary newspaper reports. There is an executive manager for the organisation as a whole, and a separate manager for each of the Lifestyles and Employment units. Each staff member in the Employment unit looks after approximately 20 clients, while Lifestyles unit staff develop and present programs for individuals and small groups. Staff and management in both units expressed a strong sense of collegiality. While the two units are aware of each other they consider themselves to be operating independently, having different clients and different sources of funding.

The organisation has two main sources of funding. The Employment unit has, to date, received block funding from the Australian Federal Government, while the Lifestyles unit is funded by Victorian State Government grants. The relationship between the Federal Government and the organisation is defined contractually and reflects the introduction of business ideology to the NFP sector. These changes were 
seen as potentially disruptive requiring the organisation to adopt a more business-like approach in an attempt to maintain performance.

The Federal Government has decided to fund open employment agencies on the basis of the number of clients they find employment for rather than by a set grant (block funding) that was paid irrespective of the number of clients who had been found employment. This change had been mooted for a number of years and management decided to improve Employment unit staff performance by offering a bonus. The bonus offered consisted of an additional month's pay if they were able to exceed their specified quota of clients placed in employment. The bonus scheme was easily understood, and supported by Employment unit staff. However, management did not extend the bonuses to Lifestyles unit staff as it was considered to be inappropriate.

\section{Research Method}

The research question is: Are employees of NFP organisations motivated by satisfaction from their work, or are they motivated by extrinsic rewards?

The small-sample $t$-test was used to analyse the data, constituting employee responses to six statements indicating intrinsic or extrinsic orientation of the reward. The statements were:

- I am satisfied with my pay

- I believe that bonus schemes can increase work performance

- I would prefer a reward system based on individual rather than team outcomes

- I am motivated by the achievements of my clients

- Working at the organisation allows me to achieve a good work/life balance

- I have fun while working at the organisation

Participants indicated their opinions to the six statements by circling a number, one to five, on a fivepoint likert scale. Response categories ranged from strongly disagreeing to strongly agreeing. Respondents returned 52 useable responses. The questionnaire was developed in conjunction with a manager of the organisation.

To understand the factors that motivate employees, the null hypothesis to be tested is:

\section{Ho: Employees are not motivated by intrinsic rewards.}

\section{Statistical analysis}

The statistics reported in the tables below reveal staff perceptions, from across the organisation. The response rate was 87 per cent. The significance level adopted is 5 per cent. $t$-test results for the data (and whether $p>.05$ or $p<.05$ ) are highlighted immediately below the relevant table. 


\section{TABLE 1}

I am satisfied with my pay

\begin{tabular}{|c|c|c|c|c|c|}
\hline & & Frequency & Percent & Valid Percent & $\begin{array}{c}\text { Cumulat iv e } \\
\text { Percent }\end{array}$ \\
\hline \multirow[t]{6}{*}{ Valid } & Strongly Disagree & 2 & 3.8 & 3.9 & 3.9 \\
\hline & Disagree & 14 & 26.9 & 27.5 & 31.4 \\
\hline & Neutral & 14 & 26.9 & 27.5 & 58.8 \\
\hline & Agree & 19 & 36.5 & 37.3 & 96.1 \\
\hline & Strongly Agree & 2 & 3.8 & 3.9 & 100.0 \\
\hline & Total & 51 & 98.1 & 100.0 & \\
\hline Missing & Sy stem & 1 & 1.9 & & \\
\hline Total & & 52 & 100.0 & & \\
\hline
\end{tabular}

\section{One-Sample Test}

\begin{tabular}{|c|c|c|c|c|c|c|}
\hline & \multicolumn{6}{|c|}{ Test Vaue $=3$} \\
\hline & \multirow[b]{2}{*}{$\mathrm{t}$} & \multirow[b]{2}{*}{ df } & \multirow[b]{2}{*}{ Sg. (2-ta ed) } & \multirow{2}{*}{$\begin{array}{c}\text { Mean } \\
\text { D fference }\end{array}$} & \multicolumn{2}{|c|}{$\begin{array}{l}95 \% \text { Conf dence } \\
\text { Interv a of the } \\
\text { D fference }\end{array}$} \\
\hline & & & & & Lower & Upper \\
\hline I am sat sf ed wth my pay & .711 & 50 & .481 & .098 & -.18 & .38 \\
\hline
\end{tabular}

Table 1 results are not significant $(t=.711, p>.05)$; there is no statistically significant difference between those who agreed and those who disagreed with the statement. 41 per cent of employees agreed with the statement, "I am satisfied with my pay", 34 per cent disagreed and 27 per cent were ambivalent about satisfaction with their pay. Hence, we cannot say that employees were motivated solely by extrinsic rewards. This highlights Herzberg's (2003) conclusion that pay does not motivate; rather, it is a "hygiene" factor.

\section{TABLE 2}

I believe that bon us schemes can increase work performance

\begin{tabular}{|c|c|c|c|c|c|}
\hline & & Frequency & Percent & Valid Percent & $\begin{array}{c}\text { Cumulativ e } \\
\text { Percent }\end{array}$ \\
\hline \multirow[t]{6}{*}{ Valid } & Strongly Disagree & 3 & 5.8 & 5.8 & 5.8 \\
\hline & Disagree & 8 & 15.4 & 15.4 & 21.2 \\
\hline & Neutral & 16 & 30.8 & 30.8 & 51.9 \\
\hline & Agree & 14 & 26.9 & 26.9 & 78.8 \\
\hline & Strongly Agree & 11 & 21.2 & 21.2 & 100.0 \\
\hline & Total & 52 & 100.0 & 100.0 & \\
\hline
\end{tabular}

\section{One-Sample Test}

\begin{tabular}{|c|c|c|c|c|c|c|}
\hline & \multicolumn{6}{|c|}{ Test Va ue $=3$} \\
\hline & \multirow[b]{2}{*}{$\mathrm{t}$} & \multirow[b]{2}{*}{$\mathrm{df}$} & \multirow[b]{2}{*}{ Sg. (2-ta ed) } & \multirow{2}{*}{$\begin{array}{c}\text { Mean } \\
\text { Dfference }\end{array}$} & \multicolumn{2}{|c|}{$\begin{array}{l}95 \% \text { Conf dence } \\
\text { Interv a of the } \\
\text { D fference }\end{array}$} \\
\hline & & & & & Lower & Upper \\
\hline $\begin{array}{l}\text { I be eve that bonus } \\
\text { schemes can ncrease } \\
\text { work performance }\end{array}$ & 2.629 & 51 & .011 & .423 & .10 & .75 \\
\hline
\end{tabular}


The response to the statement "I believe that bonus schemes can increase work performance" (Table 2) was significant $(t=2.629, p<.05)$. Employees did believe that bonus schemes can increase work performance. This concurs with Ryan and Deci (2000) who state that the efficacy of an extrinsic reward is linked with the beliefs of the employee. The apparent motivation of the extrinsic reward is, in fact, linked with the belief of employees that the task being undertaken is worthwhile.

\section{TABLE 3}

would prefer a reward system based on my individual outcomes rather than based on my team outcomes

\begin{tabular}{|ll|r|r|r|r|}
\hline & & & & $\begin{array}{c}\text { Cumulativ e } \\
\text { Percent }\end{array}$ \\
\hline Valid & Strongly Disagree & 5 & 9.6 & 10.2 & 10.2 \\
& Disagree & 18 & 34.6 & 36.7 & 46.9 \\
& Neutral & 19 & 36.5 & 38.8 & 85.7 \\
& Agree & 3 & 5.8 & 6.1 & 91.8 \\
& Strongly Agree & 4 & 7.7 & 8.2 & 100.0 \\
& Total & 49 & 94.2 & 100.0 & \\
Missing & Sy stem & 3 & 5.8 & & \\
Total & & 52 & 100.0 & & \\
\hline
\end{tabular}

One-Sample Test

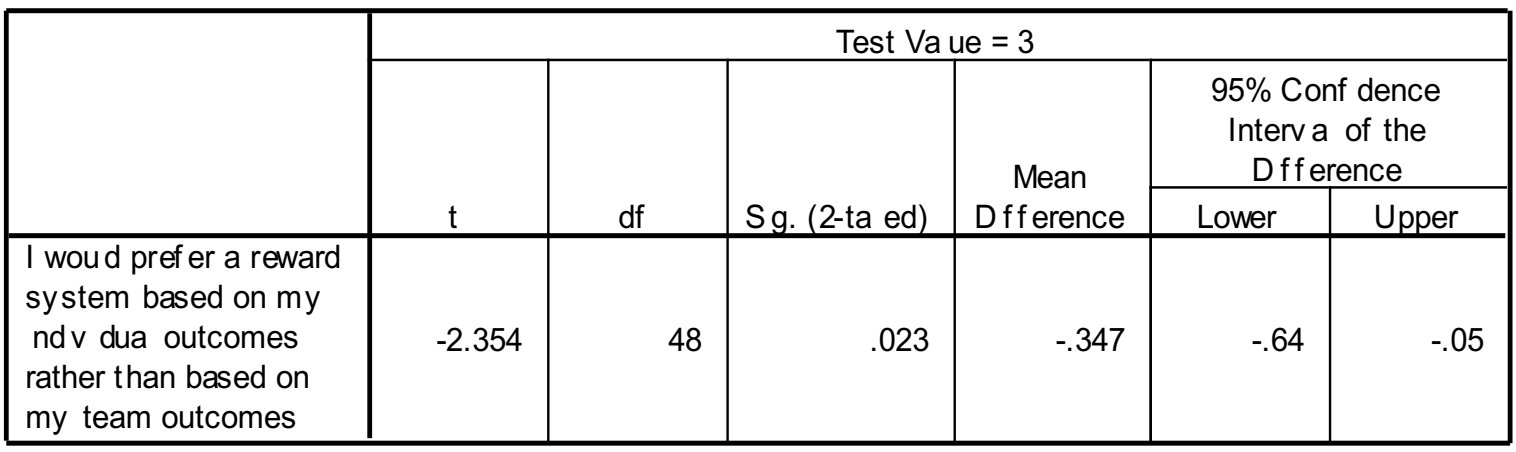

Table 3 results were statistically significant $(t=-2.354, p<.05)$. Employees did not (note the - ve $t$ value) prefer a reward system based on individual outcomes. This result further indicates the ambiguous nature of individual extrinsic rewards as motivators.

\section{TABLE 4}

I am motivated by the achievements of my clients

\begin{tabular}{|c|c|c|c|c|c|}
\hline & & Frequency & Percent & Valid Percent & $\begin{array}{c}\text { Cumulat iv e } \\
\text { Percent }\end{array}$ \\
\hline \multirow[t]{5}{*}{ Valid } & Disagree & 2 & 3.8 & 4.2 & 4.2 \\
\hline & Neutral & 4 & 7.7 & 8.3 & 12.5 \\
\hline & Agree & 22 & 42.3 & 45.8 & 58.3 \\
\hline & Strongly Agree & 20 & 38.5 & 41.7 & 100.0 \\
\hline & Total & 48 & 92.3 & 100.0 & \\
\hline Missing & Sy stem & 4 & 7.7 & & \\
\hline Total & & 52 & 100.0 & & \\
\hline
\end{tabular}




\section{One-Sample Test}

\begin{tabular}{|c|c|c|c|c|c|c|}
\hline & \multicolumn{6}{|c|}{ Test Va ue $=3$} \\
\hline & \multirow[b]{2}{*}{$t$} & \multirow[b]{2}{*}{ df } & \multirow[b]{2}{*}{ Sg. (2-ta ed) } & \multirow{2}{*}{$\begin{array}{c}\text { Mean } \\
\text { D ff erence }\end{array}$} & \multicolumn{2}{|c|}{$\begin{array}{l}95 \% \text { Conf dence } \\
\text { Interv a of the } \\
\text { Dfference }\end{array}$} \\
\hline & & & & & Lower & Upper \\
\hline $\begin{array}{l}\text { I am mot vated by } \\
\text { the ach evements } \\
\text { of my c ents }\end{array}$ & 11.025 & 47 & .000 & 1.250 & 1.02 & 1.48 \\
\hline
\end{tabular}

Table 4 results are significant $(t=11.025, p=.000)$. Employees agreed that they were motivated by the achievement of their clients. This emphasises the importance of intrinsic rewards as motivators, and is further evidence of agreement with Herzberg's (2003) argument.

These results (Tables 3 and 4) clearly emphasise the importance of intrinsic rewards to employees. Table 4 results, in particular, highlight the importance of the mission of a NFP organisation as a source of motivation for its employees.

\section{TABLE 5}

Working at the organisation allows me to achieve a good work / life balance

\begin{tabular}{|c|c|c|c|c|c|}
\hline & & Frequency & Percent & Valid Percent & $\begin{array}{c}\text { Cumulativ e } \\
\text { Percent }\end{array}$ \\
\hline \multirow[t]{5}{*}{ Valid } & Disagree & 7 & 13.5 & 13.5 & 13.5 \\
\hline & Neutral & 7 & 13.5 & 13.5 & 26.9 \\
\hline & Agree & 22 & 42.3 & 42.3 & 69.2 \\
\hline & Strongly Agree & 16 & 30.8 & 30.8 & 100.0 \\
\hline & Total & 52 & 100.0 & 100.0 & \\
\hline
\end{tabular}

One-Sample Test

\begin{tabular}{|c|c|c|c|c|c|c|}
\hline & \multicolumn{6}{|c|}{ Test Vaue $=3$} \\
\hline & \multirow[b]{2}{*}{$\mathrm{t}$} & \multirow[b]{2}{*}{$d f$} & \multirow[b]{2}{*}{ Sg. (2-ta ed) } & \multirow{2}{*}{$\begin{array}{c}\text { Mean } \\
\text { D ff erence }\end{array}$} & \multicolumn{2}{|c|}{$\begin{array}{l}95 \% \text { Conf dence } \\
\text { Interv a of the } \\
\text { D fference }\end{array}$} \\
\hline & & & & & Lower & Upper \\
\hline $\begin{array}{l}\text { Work ng at the } \\
\text { organ sat on a ows } \\
\text { me to ach eve a good } \\
\text { work / fe ba ance }\end{array}$ & 6.549 & 51 & .000 & .904 & .63 & 1.18 \\
\hline
\end{tabular}

The statistically significant result of Table $5(t=6.549, p=.000)$ strengthens the argument that intrinsic rewards are important motivators to employees of this organisation. Obviously, work/life balance is an outcome of the particular employment environment, and this response of employees adds weight to the hypothesised importance of intrinsic rewards as motivators. 


\section{TABLE 6}

I have fun while working at the organisation

\begin{tabular}{|c|c|c|c|c|c|}
\hline & & Frequency & Percent & Valid Percent & $\begin{array}{c}\text { Cumulativ e } \\
\text { Percent }\end{array}$ \\
\hline \multirow[t]{5}{*}{ Valid } & Disagree & 2 & 3.8 & 3.8 & 3.8 \\
\hline & Neutral & 9 & 17.3 & 17.3 & 21.2 \\
\hline & Agree & 29 & 55.8 & 55.8 & 76.9 \\
\hline & Strongly Agree & 12 & 23.1 & 23.1 & 100.0 \\
\hline & Total & 52 & 100.0 & 100.0 & \\
\hline
\end{tabular}

One-Sample Test

\begin{tabular}{|c|c|c|c|c|c|c|}
\hline & \multicolumn{6}{|c|}{ Test Va ue $=3$} \\
\hline & \multirow[b]{2}{*}{$\mathrm{t}$} & \multirow[b]{2}{*}{$d f$} & \multirow[b]{2}{*}{ Sg. (2-ta ed) } & \multirow{2}{*}{$\begin{array}{c}\text { Mean } \\
\text { Dfference }\end{array}$} & \multicolumn{2}{|c|}{$\begin{array}{c}95 \% \text { Conf dence } \\
\text { Interva of the } \\
\text { Dfference }\end{array}$} \\
\hline & & & & & Lower & Upper \\
\hline $\begin{array}{l}\text { I hav e fun wh e work ng } \\
\text { at the organ sat on }\end{array}$ & 9.382 & 51 & .000 & .981 & .77 & 1.19 \\
\hline
\end{tabular}

Table 6 results were significant $(t=9.382, p=.000)$. Employees clearly indicated that they do have fun while working at the organisation: 78.9 per cent of respondents agreed that they have fun while working at the organisation.

\section{Discussion}

The results reported above lead to a rejection of the null hypothesis. Employees of this organisation did appear to be motivated by intrinsic rewards. Our results question the conclusions of Gupta and Mitra (1998) that extrinsic rewards are good motivators.

A significant proportion of employees were ambivalent about satisfaction with their pay. If employees are unsure about whether or not they are satisfied with their pay, then pay cannot be a prime source of motivation for them. This is in line with Herzberg's (2003) argument that pay is a "hygiene" factor, and does not satisfy.

Employees, though, did agree that bonus schemes can improve performance. However, whilst a bonus is an extrinsic reward, this does not diminish the importance of intrinsic rewards. As Ryan and Deci (2000) state, extrinsically motivated behaviours are the outcome of individuals believing that the activity for which the bonus was received is socially significant, and valued by their colleagues, and leads to a sense of belonging. Thus, the real value of the bonus as a motivator is that it reinforces the intrinsic reward of feeling connected; of having done something worthwhile.

The response in the affirmative to the statement, "I am motivated by the achievements of my clients" was particularly reinforcing of the importance of intrinsic rewards. Most staff reported being motivated by the achievements of their clients, indicating the importance of the mission of the organisation as a source of motivation. This supports the findings of Holcombe (1995) in the case of the Grameen bank. It also supports the argument of Ryan and Deci (2000), Frey (1997), Etzioni (1988) - who states that individuals may derive utility from non-economic factors or rewards - and Larson (1977), who argue that serving the public good and control over the work environment can modify the behaviour of individuals.

The survey data support the contention of Deckop and Cirka (2000), that intrinsic rewards have a greater impact in NFP organisations. The results also support the contention of Berry, Broadbent and 
Otley (1995), that people working in the caring services are more concerned with doing a worthwhile job than they are with remuneration. Further, the results support the suggestion made by Brown and Yoshioka (2003), that money is perceived as a means to an end and is a secondary matter to NFP staff since the majority of respondents reported being not dissatisfied with their pay.

The apparent predominance of intrinsic motivation in this organisation supports Herzberg's (2003) contention that pay is a "hygiene" factor and not a real motivator; and Jobome (2006), who found that intrinsic rewards dominated extrinsic rewards in UK NFPs. This is supported by the findings regarding having fun at work (Schepers et al. 2005), and the importance of the work/life balance. These two statements received considerable support from the survey respondents, which support seriously questions a commonly-held belief that extrinsic rewards are the single-most important motivator.

\section{Conclusions}

This study was undertaken to answer the question of the value of intrinsic rewards as motivators for employees in this organisation. Intrinsic motivational factors have been found to be significant, in both the presence of an employee bonus scheme and in its absence. This finding of the motivational importance of intrinsic factors is across the whole organisation, irrespective of the quite varying conditions under which employees of the organisation work; and is in support of Jobome (2006) who argues that in UK NFPs intrinsic rewards dominate extrinsic. Extrinsic motivators do play a role, but not to the extent that classical agency theory suggests. The findings of this paper support the contentions of Etzioni (1988) and Larson (1977), that people are motivated by non-economic rewards.

The results appear to indicate that classical agency theory cannot adequately explain the motivation of staff in the NFP sector. In addition, the importance of intrinsic motivators highlights the importance of context in the motivation of staff, and the need for further research into this aspect of motivation. Human behaviour is complex and explanations of motivation need to consider carefully the organisational context (Jobome, 2006). It is through the organisation that staff are able to work with clients and witness their successes, achieve a good work/life balance and have fun at work. The results reported in this paper are gained from one NFP organisation and therefore the conclusions must be tentative. However, the findings do indicate the direction of future research.

\section{Bibliography}

Baiman, S. 1990, Agency Research in Management Accounting: A Second Look, Accounting, Organizations, and Society, 15 (4): 341-370.

Berry A., J. Broadbent and D. Otley 1995, Management Control: Theories, Issues and Practices, Macmillan, London.

Bouillon, M., G. Ferrier, M. Stuebs (jr) and T. West 2006, The Economic Benefit of Goal Congruence and Implications for Management Control Systems, Journal of Accounting and Public Policy, 265298.

Brown, W. and C. Yoshioka 2003, "Mission Attachment and Satisfaction as Factors in Employee Retention", Nonprofit Management \& Leadership, 14 (1): 5-18.

Dowling, B. and R. Richardson 1997, Evaluating Performance Related Pay for Managers in the National Health Service, International Journal of Human Resource Management, 8 (3): 348-366.

Etzioni, A. 1988, The Moral Dimension, towards a New Economics, New York: The Free Press.

Eisenhardt, K. M. 1989, Agency theory: An assessment and review, Academy of Management Review, 14 (1): 57-74.

Frey, B. 1997, "On the Relationship Between Intrinsic and Extrinsic Work Motivation", International Journal of Industrial Organisation, 15, 427 - 439.

Gaertner, K. and G. Gaertner 1985, Performance - contingent Pay for Federal Managers, Administration \& Society, 17 (1): 7-20. 
Graffam, J., A. Noblet, J. Crosbie and B. Lavelle 2005, Keeping Quality People Engaged: Workforce Satisfaction Within the Disability Employment Industry, Final Report, Faculty of Health and Behavioural Sciences, Deakin University.

Gupta, N. and A. Mitra 1998, The Value of Financial Incentives, ACA Journal, Autumn, 58-66.

Herzberg, F. 2003, “One More Time: How Do You Motivate Employees?” Harvard Business Review, January, $87-96$.

Holcombe 1995, Managing to Empower, London and New Jersey, Zed Books.

Jensen, M. C. and W. H. Meckling 1976, Theory of the Firm: Managerial Behavior, Agency Costs and Ownership Structure, Journal of Financial Economics, 3 (4): 305-360.

Jobome, G. 2006, Management Pay, Governance and Performance: The Case Of Large UK Nonprofits, Financial Accountability \& Management, 22 (4): 331-358.

Larson, M. 1977, The rise of Professionalism, Berkeley, CA: University of California Press.

Marsden, D. and R. Richardson 1994, Performing for Pay: The Effects of 'Merit Pay' on Motivation in a Public Service, British Journal of Industrial Relations, 32 (2): 243-61.

O’Donnell, M. 1998, Creating a Performance Culture? Performance-Pay in the Australian Public Service, Australian Journal of Public Administration, 57 (3): 28-40.

O'Donnell, M. and J. Shields 2002, Performance Management and the Psychological Contract in the Australian Federal Public Sector, The Journal Of Industrial Relations, 44 (3): 435-457.

OECD, 1993, Private Pay for Public Work: Performance-related pay for public sector managers, Paris.

Preston, A. 1989, "The Nonprofit Worker in a For-Profit World”, Journal of Labor Economics, 7, 4, 438-463.

Redman, T., E. Snape, D. Thompson and F. Y. Ka-Ching 2000, Performance Appraisal in an NHS Hospital, Human Resource Management Journal, 10 (1): 48-62.

Roomkin, M. and B. Weisbrod 1999, "Managerial Compensation and Incentives in For-Profit and Nonprofit Hospitals", Journal of Law, Economics, and Organisations, 15, 750-781.

Ryan, M. and E. Deci 2000, Intrinsic and Extrinsic Motivations: Classical Definitions and New Directions, Contemporary Educational Psychology, 25, 54-67.

Schepers C., S. De Gieter, R. Pepermans, C. Du Bois C, R. Caers and M. Jegers 2005, How Are Employees of the Nonprofit Sector Motivated?, Nonprofit Management \& Leadership, 16 (2): 191208.

Speckbacher, G. 2003, "The Economics of Performance management in Nonprofit Organizations", Nonprofit Management \& Leadership, 13, 3, 267-281.

Weisbrod, B. 1983, "Non-profit and Proprietary Sector Behavior: Wage Differentials Among Lawyers", Journal of Labor Economics, 1, 3, 246-263.

Williams, R. S. 1998, Performance Management. London: International Thomson Business Press. 
